\title{
Can We Speak of Ghettos in Czech Cities?
}

\author{
MichAELA STEJSKALOVÁ \\ Faculty of Social Studies, \\ Masaryk University
}

This paper covers the processes of ghettoization in socially excluded areas in the Czech Republic that are settled mainly by the Roma. I have attempted to document the logic of ghettoization using the case of an area called Poschla that emerged in Vsetín in 2006. On the basis of semistructured interviews with inhabitants and social workers, I endeavoured to find out whether Poschla was in the process of ghettoization. From the interviews and other collated data, I searched for signs of ghettoization and social exclusion as we know them from sociological theory, especially drawing from the ideas of Loïc Wacquant.

\section{INTRODUCTION}

The Czech Republic has a significant population of Roma inhabitants, many of whom are living in socially excluded areas that are sometimes designated as ghettos. This paper explores the usage of the term ghetto in relation to the neighbourhoods where the Czech Roma population live as well as the main constitutional characteristics of socially excluded Roma areas. ${ }^{1}$ The analysis is based on a case study of Vsetín, which is located in the eastern part of the Czech Republic, where I have observed the process of social exclusion and, as argued here, ghettoization in one of its neighbourhoods established in 2006.

The neighbourhood of Poschla emerged in September 2006 when thirty-six families $^{2}$ (or about 230 people) were moved from a dilapidated house in the city centre to the very edge of the town. An additional six families consisting of about seventy people were also forced to move out of the county to a few small, outlying villages. ${ }^{3}$ This study focuses on Poschla, later comparing its situation to other socially excluded Roma areas. There will be no focus on the segregation that occurs in Ceri Peach's work on ghettos in Britain, ${ }^{4}$ and the readers' attention will be directed toward the sociologically relevant characteristics of life within Czech Roma neighbourhoods and comparisons with Wacquant's understanding of the ghetto. ${ }^{5}$

\footnotetext{
1 The term 'socially excluded Roma area' is the result of political and academic debates, and as with the term ghetto, it is used merely as a descriptive designation instead of an analytical category.

2 Eva Stejskalová, 'Na Vsetíně začalo velké stěhování', Vsetín municipality website, 10 October 2006 <http:/ / www.vsetin.eu/stehovani-romu-z-pavlacoveho-domu-u-polikliniky-zacalo/d416128/p1=6528> [accessed 28 March 2013].

${ }^{3}$ Klára Vomastková, Vystěhování Romů ze Vsetína na Jesenicko a Prostějovsko. Popis a analýza dopadů na romské rodiny, práci obecních úřadů, krajské samosprávy a NNO působících v regionu (Brno: Masarykova Univerzita v Brně, 2011).

4 Ceri Peach, 'Does Britain have ghettoes?', Transactions of the Institute of British Geographers, 21 (1996), 216-35.

${ }^{5}$ Loïc Wacquant, 'A Janus-faced Institution of Ethnoracial Closure: A Sociological Specification of the Ghetto', in The Ghetto: Contemporary Global Issues and Controversies, ed. by Ray Hutchison and Bruce D.
} 
In order to reach this aim, I will conceptualize the term ghetto for the purpose of this paper. In addition, I will introduce the topic of the Roma living in the Czech Republic and subsequently, the results of my own research, clarifying the process of ghettoization in the region. Finally, I will compare Poschla to other, similar areas and answer the question, 'can and should we speak about ghettos in the Czech Republic?'.

I compiled this case study during a volunteer placement with a local NGO where I conducted twelve semi-structured interviews with the inhabitants of Poschla. To ensure anonymity, I use pseudonyms for these interviewees throughout the paper. In addition, I interviewed five social workers and conducted a variety of informal conversations with inhabitants over the duration of about six months. Furthermore, I have examined other research concerning Poschla ${ }^{6}$ as well as internet media, analysing the way it informs the public about the inhabitants of the neighbourhood. Many socially excluded Roma areas have already been researched by social scholars, ${ }^{7}$ allowing for comparisons with these studies.

\section{THEORETICAL BACKGROUND}

It would be fruitless to replicate what Wacquant has already contributed to the sociological world when he constructed a 'rigorous sociological concept of ghetto' .8 However, it is important to stress the most significant characteristics that can be used for comparison. Collin's sociological dictionary defines a ghetto as a 'segregated area of the city characterized by common ethnic and cultural characteristics [...] today it designates not just the areas inhabited by culturally and ethnically homogenous group, but also the concentration of socially disadvantaged groups and minorities in the poorest inner parts of the city'. ${ }^{9}$ However, this definition reflects a so-called folk concept of a ghetto that is often also used by wellknown scholars such as Gottdiener and Budd, ${ }^{10}$ who have discussed areas in British cities inhabited by immigrants. Additionally, the definition refers to the classic study by Louis Wirth, 11 who claimed that Jewish ghettos evolved into and were

Haynes (Boulder: Westview Press, 2012), pp. 1-31; and Loïc Wacquant, Urban Outcasts: A Comparative Sociology of Advanced Marginality (Cambridge: Polity Press, 2008).

${ }^{6}$ Jakub Grygar and Tereza Stöckelová, Př́činy a souvislosti stěhování vsetínských Romů z pavlačového domu č. p. 1336 v ř́inu 2006. Zpráva z šetření (Brno: Masarykova Univerzita v Brně, 2007); and Vomastková, Vystěhování Romů.

7 Jaroslav Haušild, 'Kořeny chánovských problémů', in Romové a Cikáni - neznámí a známí. Interdisciplinární pohled, ed. by Marek Jakoubek and Lenka Budilová (Voznice: LEDA, 2008), pp. 83-93; Lukáš Radostný and Michal Růžička, 'Masokombinát Kladno: výzkumná zpráva', in "Romové" v osídlech sociálního vyloučení, ed. by Marek Jakoubek and Tomáš Hirt (Plzeň: Aleš Čeněk, 2007), pp. 24287; and Jana Temelová and Josef Novák, 'Most, Sídliště Chánov', in Segregace v České republice: Stav a vývoj, príčiny a důsledky, prevence a náprava, ed. by Luděk Sýkora (Praha: Centrum pro výzkum měst a regionů, Př́rodovědecká Fakulta Univerzity Karlovy v Praze, 2007), pp. 108-16.

8 Wacquant, 'A Janus-faced Institution', p. 2.

9 David Jary and Julia Jary, Collins Dictionary of Sociology (Glasgow: Harper Collins publishers, 1991), p. 258.

10 Mark Gottdiener and Leslie Budd, Key Concepts in Urban Studies (London: Sage publications, 2005).

11 Louis Wirth, The Ghetto (Chicago: Phoenix, 1928). 
maintained as tools of isolation, developing in the absence of a means of communication between the Jews and the majority. To Wirth, ghettos were the result of an unconscious crystallization of the needs and practices on the side of the Jews.

Wacquant challenges these notions and claims that the term ghetto should only be applied to those areas that are involuntarily inhabited by people of one race, ethnicity, or religion, as the processes at work in poor and ethnically mixed neighbourhoods are qualitatively different from those taking place in ghettos. ${ }^{12}$ In contrast to these areas, ghettos are characterized by constraint, entrapment, exclusivity, encompassment, inward orientations, and rigidity regarding the stigma that people bear. ${ }^{13} \mathrm{He}$ views ghettos as 'an ethnoracial formation that combines and inscribes in the objectivity of space and group-specific institutions all four major elementary forms of racial domination, namely, categorization, discrimination, segregation and exclusionary violence'. ${ }^{14}$ Originally, the ghettos of African Americans were integrated socially and structurally because they contained the inhabitants of all classes. Orthodox ghettos served as a reservoir for disposable industrial labour, but in the post-industrial era, they became dumping sites for populations deemed to be of no political or economical use for society. ${ }^{15}$

However, according to Wacquant's understanding, ${ }^{16}$ it is not sufficient to have a segregated, poor, or even dishonoured population living within the specified area to designate it as a ghetto. ${ }^{17}$ What is significant is the double function it serves for both the majority and the confined population: on the one hand, it is an instrument of control and power for the dominant group, but on the other hand, it is a means of protection that intensifies the social exchange inside the ghetto. Another important characteristic is the impermeability of physical and, especially, social boundaries between these two groups.

In this respect, Marcuse and Van Kempen discuss ghettos as realms of exclusion. They see ghettos as concentrated areas used for the involuntary separation of a group, constraining populations that dominant groups regard as inferior. ${ }^{18}$ Majority groups have abandoned these places, and when externally examined, they have negative social, political, and economic relations with the rest

\footnotetext{
${ }^{12}$ Loïc Wacquant, 'Ghetto', in International Encyclopedia of the Social and Behavioral Sciences, ed. by Neil J. Smelser and Paul B. Baltes (Amsterdam: Elsever, 2004), <http:// sociology.berkeley.edu/faculty/wacquant/wacquant_pdf/GHETTO-IESBS.pdf> [accessed 23 March 2013]; and Loïc Wacquant, 'Three Pernicious Premises in the Study of the American Ghetto', International Journal of Urban and Regional Research, 21 (1997), 341 -53.

${ }^{13}$ Wacquant, 'A Janus-faced Institution', p. 22. These will be the main characteristics with which the Czech situation will be compared.

${ }^{14}$ Wacquant, 'Three Pernicious Premises', p. 343.

${ }^{15}$ Zygmunt Bauman, Wasted Lives (Cambridge: Polity Press, 2004).

16 Wacquant, 'A Janus-faced Institution'.

${ }^{17}$ Throughout his academic work, Wacquant has put significant effort into showing that the segregated areas in American cities differ from those in Europe. However, he has an exception concerning the Roma neighbourhoods in East and South European cities: 'This population ... has long been marginalized in both monoethnic rural villages and urban districts combining the four structural components of stigma, constraint, spatial enclosure, and institutional parallelism'. Wacquant, 'A Janus-faced Institution', p. 19.

18 Peter Marcuse and Ronald van Kempen, Globalizing Cities: A New Spatial Order? (Oxford: Blackwell Publishers, 2000).
} 
of the city. At first glance, these negative relations can be seen as anomy, but researchers studying ghettos in depth claim that there is no absence of norms or inner structure in these neighbourhoods. ${ }^{19}$ On the contrary, a kind of anti-structure can be discovered - an intentional undermining of all the values and norms that the dominant group take for granted together with the parallel structures that are meant to compensate for everything from which the inhabitants have been excluded.

This anti-structure and the dissolution of dominant norms and beliefs become the main reasons behind the majority's urge to isolate such minority groups and stigmatize their lifestyle. ${ }^{20}$ This effort closely relates to the trend of criminalization of poverty, ${ }^{21}$ where the 'human waste' needs to be kept in closed containers. Therefore, ghettos serve as ethno-racial prisons, which limit freedom and opportunity in the dominant society and allow for the constant control and surveillance of underprivileged groups. All dominant institutions operating in the ghetto serve a similar purpose, and this applies most noticeably to schools.

In his work on American schools, Richard Kahlenberg shows that schools in the ghetto are a tool of control. He maintains this stance despite the desegregation of American schools in deprived neighbourhoods. ${ }^{22}$ The quality of education in segregated schools is significantly lower, as there are fewer qualified teachers and substandard material equipment. According to Kenneth Clark, the American public schooling of his time was based on a few presuppositions, which maintained the perception of African American children as uneducable. ${ }^{23}$ They were systematically categorized and labelled, but they were not taught satisfactorily, and as a result, they inevitably failed to receive a basic level of education. Clark also claims that African American children were not respected as human beings, and their potential was ignored in the name of academically irrelevant factors, such as their manners, way of speech, or clothing. ${ }^{24}$ School in the ghetto does not prepare children for future occupations or higher education. Instead, it categorizes the children based on their ethnicity and origin and binds them to the neighbourhood, which means that their chances of integrating into the broader society are very limited..$^{25}$

It is obvious that an individual's ability to better his or her life and remove the stigma associated with the group lies beyond the emergence and maintenance of the ghetto within which he or she is confined. Observing the main attributes of the

\footnotetext{
${ }^{19}$ Kenneth B. Clark, Dark Ghetto (New York: Harper and Row publishers, 1965); Wacquant, Urban Outcasts; and William J. Wilson, More than just Race: Being Black and Poor in the Inner City (New York: Norton and Company, 2009).

${ }^{20}$ Herbert Gans, 'Involuntary segregation and the Ghetto: Disconnecting Process and Place', City and Community, 7 (2008), 353-57.

${ }^{21}$ Bauman, Wasted Lives; and Loïc Wacquant, Punishing the Poor: The Neoliberal Government of Social Insecurity (Durham: Duke University Press, 2009).

${ }^{22}$ Richard D. Kahlenberg, All Together Now: Creating Middle Class Schools through Public School Choice (Washington D. C: Brookings institution press, 2001).

${ }^{23}$ Clark, Dark Ghetto, p. 126. One group of presuppositions saw the inability to educate children as a result of their racial and cultural background, whilst the other group supposed that the African American people would never have the opportunity to undertake anything other than low-qualified jobs, meaning there was no point in educating them.

24 Ibid.

${ }^{25}$ Loïc Wacquant, Urban Outcasts, p. 85.
} 
Roma population living in the Czech Republic, I will examine their perceived inferiority as a group, and finally, I will move to the case study of Poschla.

\section{ROMA IN THE CZECH REPUBLIC}

The Czech Republic has an overall population of approximately ten million people, and estimates of the Roma ethnic group in the country indicate that there are somewhere between 160,000-350,000 individuals. For example, Jitka Langhamrová and Tomáš Fiala ${ }^{26}$ estimated the number of the Roma in 2003 to be 160,000-200,000 people; on the other hand, the European Network Against Racism ${ }^{27}$ in their recent Shadow Report estimate this number between 250,000-350,000 people. The exact number of Roma living in the Czech Republic is difficult to calculate due to the fluidity of Roma ethnicity as a category. ${ }^{28}$ Much like other national and ethnic identities, its content is always negotiated, and many Roma who have assimilated or integrated into Czech society prefer to no longer identify as such. For example, according to Gabal's research ${ }^{29}$ out of $150,000-200,000$ Roma people, only $60,000-$ 80,000 individuals are socially excluded. In current times, these numbers will probably be slightly higher, mainly because of the higher fertility rate of Roma women in comparison to non-Roma women.

Roma people live mostly in urban areas, and their situation can be characterized as an ideal type of socially excluded groups. ${ }^{30}$ This ideal type is not a 'purely synthetic construct offered for purposes of analysis, but a socio-historical abstraction from real instances of a phenomenon'. 31 The Roma struggle with multiple dimensions of exclusion, including economic, spatial, cultural, political, and symbolic exclusion. ${ }^{32}$ It is obvious that not all Roma people are socially or otherwise excluded or living in excluded areas, but those who have integrated into Czech society are usually not perceived as Roma and do not wish to be.

The Roma arrived in Central and Western Europe in the early fourteenth century. They presented themselves as pilgrims leading an itinerant life in order to be granted forgiveness for alleged crimes that they had committed against Jesus Christ (legends of the nature of these crimes vary). ${ }^{33}$ Shortly after their arrival to

\footnotetext{
26 Jitka Langhamrová and Tomáš Fiala, 'Kolik je vlastně Romů v České republice?' Demografie, 45 (2003), 23-32.

${ }^{27}$ František Valeš and Selma Muhič Dizdarevič, ENAR Shadow Report: Racism and Related

Discriminatory Practices in the Czech Republic (Brussels: ENAR Foundation, 2012), p. 8, <

http:/ / enar.helcom.cz/wp-content/uploads/2011/09/5.-Czech-Rep.pdf> [accessed 23 May 2013].

${ }^{28}$ Leo Lucassen, 'Between Hobbes and Locke. Gypsies and the limits of the modernization paradigm'

Social History, 33 (2008), 423-441.

${ }^{29}$ Ivo Gabal, Analýza sociálně vyloučených lokalit a absorpční kapacity subjektů působících v této oblasti

(Praha: MPŠV, Gabal Analysis \& Consulting, 2006), p. 27,

<http://www.mpsv.cz/files/clanky/3043/Analyza_romskych_lokalit.pdf> [accessed 23 March

2013].

${ }^{30}$ Petr Mareš, Faktory sociálního vyloučení (Praha: VÚPSV, 2006).

${ }^{31}$ Wacquant, Urban Outcasts, p. 233.

32 Petr Mareš, Faktory sociálního vyloučení.

${ }_{33}$ Ctibor Nečas, Romové v České republice včera a dnes (Olomouc: Vydavatelství Univerzity Palackého v

Olomouci, 1999), p. 21.
} 
Europe, native Europeans began to resent the Roma presence, partly on the basis of alleged Roma violations of Christian morals and partly because they suspected them of being enemy spies. ${ }^{34}$

The worst time for the Roma within the Czech territory most likely came with the reign of Leopold I., when they were expelled from the country and a law permitting the homicide of Romani men was adopted. As a result, the children were given to 'good Christian families' for their proper upbringing. ${ }^{35}$ Following this period, the eighteenth century is connected with the forced assimilation of Roma during the reign of the Empress Maria Therese. At this time they were beginning to be perceived as ordinary peasants, who were still visibly different because of the colour of their complexion, but in terms of treatment, repression was replaced with assimilation. As peasants, however, they had to settle down and stop travelling to earn their living.

During the twentieth century, the Roma in the region again witnessed severe oppression. In fact, the majority of the original Roma population from what is today the Czech Republic was killed in the Holocaust. Even before the war, however, Roma in the country lacked social and economic equality. Forced settling became even more restrictive shortly before the Second World War, when a registry of all the Roma living in the area was created. After the war, Slovak Roma moved into abandoned houses around the Czech borderlands and city centres and filled vacancies in heavy industry. This relocation was partially motivated by the desire for better living conditions and partially by the organized state policy of Roma dispersion. ${ }^{36}$

The situation of the Roma minority in the socialist era was quite difficult. According to Dena Ringold, 37 an important shift occurred when the Roma were forced to move from self-employment and the informal sector to full-time work. During this time, all persons lacking official employment for any reason (regardless of whether they held part-time work, were self-employed, or were truly unemployed) were considered parasites on society, and, as such, they could be subject to imprisonment. If both parents in a family found themselves imprisoned for unemployment, the children were institutionalised in an educational facility. In these cases, Czech society did not deem their family environment healthy enough for raising children. ${ }^{38}$

After the 1989 revolution, the Roma were acknowledged as a national minority for the first time. However, only a fragment of the Roma population has declared themselves as Roma, and therefore they cannot claim any minority rights, such as education in their mother tongue. Nowadays, at least some associations and non-government organisations, including the Museum of Romani Culture, the Roma Association of Moravia, and Romea, are aspiring to raise Roma culture and overall awareness of Roma customs and habits.

\footnotetext{
${ }^{34}$ Angus Fraser, The Gypsies (Oxford: Blackwell Publishing, 1995), p. 84.

${ }^{35}$ Jana Horváthová, Kapitoly $z$ dějin Romů (Praha: Člověk v tísni, 2002), p. 21.

${ }^{36}$ Dena Ringold, Roma and the Transition in Central and Eastern Europe: Trends and Challenges

(Washington: The World Bank, 2000), p. 5.

37 Ibid., p. 15.

38 This has been shown in the permanent exhibitions of the Museum of Romani Culture in Brno.
} 
Another major change occurred with their employability. During the socialist era, many of the Roma had industrial jobs in state factories and companies. After the revolution, the Roma were the first to be dismissed from their work not only because of the diminishing number of manual jobs, but also because of the concealed racism at that time. ${ }^{39}$ Currently, a generation of Roma children that has never observed regular working habits from family members and other close friends and relatives is maturing in the socially excluded areas. ${ }^{40}$

According to Frištenská, after the revolution interethnic conflict emerged caused by the Roma minority demanding certain rights, including language rights, cultural self-determination, and political representation, making them more visible in the public sphere. ${ }^{41}$ In addition, some extreme attitudes of the non-Roma majority became more apparent; they perceived the Roma through a lens of stereotypes and prejudices, likening them to criminals, parasites, and the welfare-dependent. Today, there is an effort by the Czech government to regulate extreme attitudes and ethnic discrimination, although this is strongly motivated by pressure from European institutions.

Interest from European institutions in the Roma is another important aspect of transition. After the opening of borders, some Roma migrated to Canada and other Western countries where they applied for asylum on the basis of the racial discrimination that they faced in the Czech Republic. The situation concerning discrimination then became the subject of much research and observation, and in 2009, research at the Fundamental Rights Agency (FRA) concluded that the Czech Roma were the most discriminated minority in Europe.

All of these aspects have shaped the mutual relations of the Roma and nonRoma living together in the Czech territory. Since their first arrival to Europe, the Roma have been systematically stigmatised, isolated, and excluded. When compulsory education was introduced, they perceived school as a means of control,42 and according to Ševčíková, even today 'for the majority of the Roma, school is a synonym for a key repression tool of the majority, a synonym for a hostile, mendacious, and incomprehensible environment, which only aims to pressure assimilation and force re-education'. ${ }^{43}$ Roma children are placed in 'practical' schools ${ }^{44}$ that have significantly poorer standards of education compared

\footnotetext{
${ }^{39}$ Saša Uhlová, ‘Dopady asimilační politiky vůči Romům z období reálného socializmu jako jeden z faktorů současného vytváření enkláv sociálně vyloučených obyvatel', in Romové: kulturologické etudy, ed. by Marek Jakoubek and Tomáš Hirt (Plzeň: Aleš Čeněk, 2004), pp. 230-47 (p. 245).

${ }^{40}$ This applies only to the Roma in socially excluded areas, where people also often take part in the black economy.

${ }^{41}$ Hana Frištenská, 'Interetnický konflikt po roce 1989 s ohledem na soužití s Romy', in Romové v České republice (1945-1998), ed. by Hana Lisá, (Praha: Socioklub, 1999), pp. 244-66 (p. 250).

42 Jean-Pierre Liégeois, Rómovia, Cigáni, kočovníci (Bratislava: Academia Istropolitana, 1995), p. 223.

43 ‘Pro většinu Romů škola stále představuje pouze synonymum klíčového [...] majority, synonymum nepřátelského, lživého a nepochopitelného prostředí, jehož jediným cílem je asimilační tlak a násilná převýchova'. Veronika Ševčíková, Sociokulturní a hudebně výchovná specifika romské minority v kontextu doby (Ostrava: Ostravská Univerzita v Ostravě, 2003), p. 116.

${ }^{44}$ In the past these were called special schools, but special education in the Czech Republic has been reformed. However, the only significant and real changes that occurred with this reform were the change in its name and the fact that children from practical schools can now continue to any secondary school. They do not often pursue secondary school, however, because Roma children are
} 
with regular schools, and they are isolated from children belonging to the majority group. As a result, their opportunities are drastically diminished. It is, thus, quite understandable that the Roma do not believe it is possible to succeed in Czech society and are searching for alternative ways to earn a living. The majority population, however, sees the situation differently and expects the Roma people to adhere to societal standards in order to be given opportunities to succeed. This notion was also present in Vsetín during the time of forced migration of the Roma people to Poschla and out of the county.

\section{Poschla as a Place Where Ghettoization is OCCURRING}

Vsetín has a population of about 28,000 inhabitants, and there are about 600 Roma people living in two relatively close and closed areas. Poschla was established as a residential neighbourhood first in 1996 when twelve flats were built for indebted and impoverished people and families. Living conditions are significantly low there. For example, common toilets and hot water are only available two days a week. The homes are located at a decontamination facility, and except for the space already created to build houses, there is no extra room to expand housing due to residual harmful gases. Despite this, there is a huge grassy area where kids often play.

Poschla is located right outside the city where the sign 'end of Vsetín' is displayed. Around the area, natural and artificial borders, such as a forest to the north; a river and a railroad to the east; and the motorway to the south and west, allow for difficult but possible access to the city and neighbouring towns and regions. The motorway, for example, can only be crossed using the pedestrian crossing located about 600 meters away from Poschla, necessitating a detour.

The inhabitants of Poschla usually go to the city by car or under the railroad, but this passage is nearly inaccessible when it is raining heavily. Poschla is located about two and a half kilometres from the city centre, and the closest non-Roma people live nearly one and a half kilometres away. The other socially excluded Roma area is located about one kilometre away in the middle of an industrial zone.

The majority of the children from both locations attend a practical school, which is located in the city centre. They mostly arrive by bus, which picks them up in the industrial zone and takes them directly to school. The inhabitants of Poschla are ninety-nine percent of Roma origin, ${ }^{45}$ whilst the inhabitants of the other area are one hundred percent Romani. This means that Vsetín has two areas inhabited exclusively by the Roma; the Roma do not occupy any other spaces in the surrounding city.

Currently, Poschla consists of the low-rise buildings that contained the former low-income housing and two three-story blocks of flats, which are made of metal containers and overlaid with colourful gypsum. They are located near the community centre that holds the local NGO. In-between the blocks of flats are grassy

not given a proper education and because practical schools teach significantly less than ordinary schools, contributing to an inequality in the children's starting positions.

45 There is one non-Roma girl living there, but residents say that she is more Roma than any of them and that skin colour does not play any role in her case. 
areas with tables and benches. The nearest building is the sewage plant that sometimes emits odours. In each block there are eighteen flats. Twelve of those flats have two rooms, totalling forty-four square metres each, and six one-room flats occupy an area of twenty-eight square metres each. Almost all the flats are overcrowded, and sometimes up to twelve people live together in two-room spaces, leading to the obvious deterioration of living conditions. The common areas of the houses are in terrible condition, displaying broken mailboxes, holes in the walls, and broken windows, despite the assertion that the buildings are vandal-resistant.

The majority of the men have experienced imprisonment, and due to their low-education, are often unemployed or under-employed on the black market. Women are usually on maternity leave or are also unemployed and dependent on social benefits. A few children currently attend the ordinary school, which is seen as a success brought about by the local NGO's activities. Unfortunately, the dark side of this success is that the influx of Romani children in ordinary schools will result in the non-Roma population enrolling at different institutions. ${ }^{46}$ The numbers of elderly are minimal because the life expectancy of Roma people is still significantly lower than the life expectancy of non-Roma people.

Poschla, therefore, is a socially excluded Roma area. This is not just because the inhabitants are socially excluded from Czech society, but also because the area itself has been spatially excluded from the city, even before the container houses were built. Socially excluded Roma areas and ghettos cannot be viewed as synonymous, however, even though in the ghettos, social exclusion par excellence takes place. The ghetto is a place of hopelessness, resignation, and aversion against the outside world. Here, adaptation to social exclusion has already taken place; the process of ghettoization becomes final when the inhabitants no longer see any real chance of leaving and when they accept that way of life and no longer aspire to be part of the majority society. In light of this, can the process of ghettoization be found in Poschla? And, if so, at what stage of this process has Poschla arrived?

First, it is important to describe what preceded the creation of Poschla, as it is clear that ghettoization did not emerge naturally. I will argue that it was created following an act of the municipality of Vsetín. Even lacking the knowledge of what preceded the establishment of this area, it is possible to demonstrate that the municipality created the ghettoization while building container houses for people from demolished balcony-access flats 47 that were located opposite the Vsetín hospital in 2006. The only available housing left for these populations existed in Poschla, and they were forced to move into the neighbourhood.

In the beginning, however, a five-storey, balcony-access building with sixtyfour flats was built in Vsetín in 1939, but the municipality did not maintain or refurbish this building during its sixty-seven year life, despite the fact that by the 1980s, the quality of life in this residence was deteriorating rapidly. Because of this, all non-Roma residents have continuously fled to more developed areas, while

\footnotetext{
${ }^{46}$ In the USA, white flight began when thirty percent of the school population became African American. See Kahlenberg, All Together Now.

${ }^{47}$ This is a type of a house in which flats are accessed through opened or closed corridors located on the outside of the building instead of through a stairway within the building. In Czech cities they usually have common bathrooms for each floor located on the balcony.
} 
different groups of Roma began to occupy the empty spaces this flight left, bringing about a near complete homogenization of the housing estate. In 2006, the poor condition of this residence was only attributed to the Roma people who lived exclusively in the building at that time. ${ }^{48}$

The problems in this building escalated in 2004 when eleven Roma families from the so-called 'House of Terror' 49 - which was meant to be demolished - moved in. Due to their relocation, the house held the largest number of the Roma families in the building since 'White flight' began in the beginning of the 1990s. Up until then eight families a year moved into the balcony-access housing when their original homes either underwent refurbishment or were demolished due to poor conditions. However, even after some of these residences were refurbished, the Roma populations were often not allowed to come back to their original houses and had to stay in this newly developing 'Roma-only house' opposite the hospital. Before the refurbishments and demolitions of municipal housing, the Roma population in Vsetín was spread out between seven different areas. At that point, they were almost all concentrated in balcony-access housing in the city centre. Afterwards, they were all moved out of the county or to Poschla. Gejza, a forty-five year-old resident, commented on the issue: 'for seventeen years we lived in that balcony-access house. Only four Roma families were there in the beginning, and then someone was smart and concentrated the Roma so that they could be seen'. Many of the inhabitants of the balcony-access house owed money for rent or energy to various extents. The municipality had the opportunity to collect on those debts directly from the state, but they did not choose to do so. In the end, they gave the people an ultimatum of either going to Poschla or living on the street. Container houses in Poschla were the result of the municipality's policies, which allowed the situation in the balconyaccess house (which was at that time one of the two Roma buildings in Vsetín) to deteriorate to such extent that moving to Poschla was the only feasible solution. As a result, Poschla evolved involuntarily from the tenants' point of view due to the municipality's poor management of the facilities.

According to Wacquant's definition, four facets of racial domination characterize a ghetto: categorization, discrimination, segregation, and exclusionary violence. ${ }^{50}$ Categorization in this respect means decision-making about the fate of a group of people on the basis of some given characteristics, such as ethnicity. Segregation and categorization along with stigmatization creates an easily exploitable faction of people. The majority of the Roma living in the Czech Republic face discrimination, and as Powell explains, 'on the streets, people point to Roma, pull faces at them and obviously avoid them [...] everyone had a ready off-the-peg anecdote to tell about Gypsy criminality [...] there has also been a dramatic intensification in anti-Gypsy feelings among young people'.51 These sentiments in the country have worsened along with recent anti-Roma demonstrations that

\footnotetext{
${ }^{48}$ Grygar and Stöckelová, Př́činy.

${ }^{49}$ This was a block of flats in Vsetín inhabited by Roma people who were widely perceived and stigmatized as problematic and dangerous.

${ }^{50}$ Wacquant, 'Three Pernicious Premises', p. 343.

${ }^{51}$ Chris Powell, 'Razor Blades Amidst the Velvet? Changes and Continuities in the Gypsy Experience of the Czech and Slovak Lands', in Gypsy Politics and Traveller Identity, ed. by Thomas Acton (Hertfordshire: University of Hertfordshire Press, 1997), pp. $90-99$ (pp. 92-93).
} 
sometimes turn violent. Exclusionary violence as an effort to eliminate difference from the realm of everyday interactions is one of the impulses behind the creation of socially excluded areas. The majority's intolerance toward the Roma people's difference results in their separation into areas where ghettoization is occurring. All of the above-mentioned facets of racial domination have emerged in Poschla, the main aim of which is to control the people and groups that the majority perceives as problematic.

The effort to control inhabitants of Poschla was discernable even before they had been forced to move there. The Mayor of Vsetín segregated and categorized these people and was quoted in the local newspapers at that time, saying:

\footnotetext{
'We won't allow any debts for rent or electricity. No long-lasting visits of whole families. We don't want to see any messes in the corridors or around the house. We won't tolerate any destruction of town property, and we won't close our eyes to any offences. If any of this happens, you'll be put out on the street.' He also pointed out that they brought the house they had been living in to the brink of destruction and stated that they should be happy to have a roof over their heads. ${ }^{52}$
}

The community coordinator and the local NGO controlled all of the Mayor's abovementioned rules for living in Poschla and regularly spent full days in the neighbourhood monitoring the residents. Another control mechanism that the State developed called Childcare Services (OSPOD) has the power to take children away from their parents if they are not attending school regularly. It also has the power to deprive parents of their social benefits for the same reason. Schools can inform the OSPOD or police if children are not in class. Additionally, regular police patrols that visit Poschla also serve as a control device. In other areas, such patrols are superficial and consist of quick drive-bys. In Poschla, however, the police make an effort to check on the inhabitants. They do not just drive by, turn around, and leave as they do in other neighbourhoods. Tenants perceive this as an act of control. 'I don't like that the police come here and check on us. Nobody is controlling the whites', explained David, a thirty-two year-old resident. When asked how they feel about non-Roma people, many inhabitants answered that they have no problem with them, but there is clearly a level of distrust that Poschla inhabitants feel toward nonRoma. These residents are faced with racism and discrimination whenever they search for employment. According to thirty-five year-old Milada, 'It's best to work as a social worker or as a teaching assistant because they take Roma people there. There's no point in having an education as a nurse or as a mechanic. No Roma will get a job like that'. The maintenance of natural and artificial boundaries only reinforces these mutual feelings of mistrust and hostility.

Spatial constraint is another important means of control that causes the inhabitants to stay in Poschla for large portions of the day. As mentioned above,

\footnotetext{
52 '”Nepřipustíme žádné dluhy za nájem a za elektřinu. Žádné mnohadenní návštěvy celých rodin. Nechceme vidět nepořádek na chodbách a kolem domu. Nebudeme tolerovat ničení městského majetku a nepřimhouříme oči nad delikty. V opačném případě jdete na ulici," a poukázal, že dům, v němž dosud Romové bydleli, zdevastovali tak, že ho město musí zbourat...'. 'Starosta určil Romům pravidla užívání bytů', Valašský denikk, 12 October 2006

<http:/ /zlin.info/article.php?ID=88771> [accessed on 28 November 2012].
} 
Poschla has clear (and to some extent impermeable) borders in the form of a motorway, a railroad, a river, and a forest. At the same time, the footpath and public lights end about 400 metres away from Poschla, continuing again when they enter the Poschla neighbourhood area. For example Justína, a forty-six year-old female, states, 'I am in Poschla all day long. I only go to town if I go shopping or if there is a religious gathering. What else would I be doing there?'. This restriction mainly affects women because men often have a car at their disposal. Children have the opportunity to attend school, but the bus picks them up in the industrial zone and drops them off in front of the school, so they also do not come into contact with many non-Roma people on the way. Fewer and fewer residents are looking for reasons to leave Poschla, and they also have no contact with any non-Roma people except those who work for the NGO.

Besides the physical boundaries in the form of the motorway, forest, river, and railroad, closure of the area from the outside occurs via two other mechanisms: stigmatization and the establishment of parallel institutions in the neighbourhood. The image of Poschla has been stigmatized in much the same way that the balconyaccess house used to be, making integration into majority society difficult and maintaining segregation, discrimination, and exclusion. Poschla was stigmatized even before container houses were built, and the tenants who moved in during 2006 carried the stigma of the balcony-access house with them. As a consequence, the non-Roma view Poschla as a dangerous no-go area and avoid it at all costs. For example, a police officer claimed that he feels 'ten minutes of horror' whenever he is in the neighbourhood. Interestingly, Poschla is perceived negatively even by the Roma living in the other socially excluded area, and other Roma people almost never visit unless they have relatives living there. Concerning the parallel institutions, the idea was established to build a shop and a kindergarten in Poschla, which the NGO fiercely opposed because they feared the closure of the neighbourhood to the outside. Yet, the Community coordinator believes that there is no point in understanding integration as forcing Roma and non-Roma families to mix, as each group would only interact with its own members, even in a mixed environment.

Closure from the inside is manifested by inhabitants' negative attitudes and reactions toward people who do not belong in Poschla. Such negative attitudes are directed not only at the non-Roma, but also at the Roma from the other part of Vsetín. One incident clearly illustrates this phenomenon. Shortly after the establishment of Poschla, a priest held a lecture in the community, and a few nonRoma people from the town wanted to attend. Some of the Roma attempted to throw them out for trespassing in the neighbourhood that they believed now belonged to them. A similar situation occurred at the International Children's day celebration when a disagreement between the children evolved into a huge conflict between the Roma from Poschla and the Roma from outside. The Roma people in Poschla fight for their own area, which they believe should not be touched by anybody else. This probably explains why there were so many conflicts with the local NGO, which attempts to improve their lives. The children brought this to my attention by always asking about my work and research and warning me that I 
should leave because it's their home. The idea of Poschla as a ghetto becomes more convincing because of this closure, both from the inside and from the outside.

One of the last characteristics of ghettos that I would like to focus on is the resignation of the inhabitants to stay in the area. This resignation can already be found in Poschla. Gejza, a forty-five year-old resident, remarked, 'We would like to move away from here, but we will stay here because everyone says that. There are not enough town flats, and even those that are available are being sold. I have had the application since we came here, and I am even looking for the flat myself, but it's hopeless'. During my stay in Poschla, I heard many similar stories about how residents believed they would die in the area without any other place to go. The tenants are sure that they are disadvantaged because they live in Poschla, but the municipality refuses to admit that any underlying prejudices exist regarding the neighbourhood. The housing market for Roma is less accessible as well as less stable in comparison to that for non-Roma people. Many inhabitants of Poschla have already dismissed the option of leaving as unrealistic, and only those who are employed are actively trying to move out. This could lead to the development of a situation similar to that of the American ghettos; the middle class will move out, and the poorest people will be left behind.

In summary, all of Wacquant's attributes of the ghetto, namely constraint, entrapment, exclusivity, encompassment, inward orientation, and the rigidity of stigma that people bear, 53 can be observed in Poschla. Therefore, it is useful to discuss ghettos in Czech cities and examine the process of ghettoization in the country in order to determine what can be done to better the situation. Ghettoization can be seen as a spiral of self-fulfilling prophecies. The processes occur in conjunction with the reactions of the excluded. The spiral in this case begins with a broad, shared space between the minority and majority. This space however, keeps narrowing, and at the bottom of the spiral of ghettoization, there is no longer a basis for mutual understanding. The options of the excluded to become part of mainstream society are therefore narrowing as well.

In Vsetín, the Roma people were originally living amongst the non-Roma population, and later they inhabited a few separated houses, but they were still equally distributed within the majority. ${ }^{54}$ Houses began to deteriorate and nobody repaired them, and as a result, the non-Roma population relocated. The combination of the increasing Roma concentration in some quarters and their deteriorating homes led to a worsening of inter-group relations followed by further stigmatization. Due to this stigmatization, non-Roma people avoided contact with the Roma, and as a result, homogeneous housing patterns came into existence. Relations between the Roma and non-Roma populations became tenser, mostly due to the noise and disorder in Roma-inhabited areas. The non-Roma people continued to complain, and without proper maintenance from the municipality, Roma houses became uninhabitable. Tenants were then stigmatized and labelled as problematic, maladaptive dodgers, and they were discriminated against in various areas of their

\footnotetext{
53 Wacquant, 'A Janus-faced Institution', p. 22.

54 This can be seen in the presentation of the former Mayor from the time as he was planning to 'solve' the so-called Roma issue, available at: <http:/ / www.cunek.info/Informace/Romove/Prezentace-Reseni-romske-problematiky.aspx> [accessed 28 November 2012].
} 
lives. These attitudes caused defensive action mainly from the young Roma, who at the same time provided the majority and, especially, the municipality with a justification for radical measures. This has resulted in the establishment of Poschla and the beginning of its ghettoization. It is impossible to discern whether Poschla is already a ghetto at this point, because the parallel social and organizational structures have not been fully established yet, but the basis for its ghettoization can nevertheless be observed.

\section{SOCIALLy EXCluded Roma AREAS As GHETTOS?}

In Czech society ghettoization exists, and we can assume that Poschla is not the only case. As the following studies of other socially excluded areas show, the concentration of Roma into distinct communities is occurring in every city where they are present. Gabal's analysis demonstrates that the majority of these areas are located in relatively small cities - more than fifty percent of socially excluded areas are located in towns with 5,000-90,000 inhabitants, and twenty-six percent are located in villages with less than 2,000 residents. In bigger cities, the socially excluded areas are to some extent ethnically mixed, but they consist predominantly of the Roma population. 55

What is concerning is the way that these areas have emerged. More than fifty percent of all researched areas came into existence in a directed way in the last ten years. ${ }^{56}$ Large Roma neighbourhoods such as Chánov in Most or Sever in Česká Lípa where originally built to accommodate the employees of big factories or mines. Chánov was meant for people who had to leave their homes in Old Most due to the existence of brown coal on these properties. However, the Roma population from Old Most was divided into three categories. The first category was perceived as nonproblematic and integrated within the majority in another neighbourhood, but the other two categories were seen as difficult to deal with and therefore moved into segregated Chánov. ${ }^{57}$ Newer socially excluded areas are the result of the need to find housing for debtors and are sometimes represented by various hostels. No matter how these areas emerged, they are almost always the end station for their tenants, as moving out is exceptional. It is not important if they arrive voluntarily or involuntarily, but as soon as they move in, they are labelled as residents of the area, and that label is quite dishonourable.

It is possible to discuss ghettoization in connection with many socially excluded areas, even though the Roma do not solely inhabit such places. For example, Chánov is an extreme case of segregation, and ninety-five percent of the population is Roma. Of this ninety-five percent, ninety-nine percent do not pay rent and are in debt. These debts are being paid partially through social benefits from the state. ${ }^{58}$ Since 1996 only cold water exists on the premises, there are no water meters, and the water bills are paid just on the basis of the number of people living there.

\footnotetext{
${ }_{55}^{5}$ Gabal, Analýza, p. 19.

56 Ibid., p. 16.

57 Temelová and Novák. 'Most, Sídliště Chánov', p. 113.

58 Ibid., p. 110.
} 
This neighbourhood has a very bad reputation and is completely isolated from the town. There are many drug addicts living there who are often responsible for crimes. Inhabitants have already resigned themselves to their situation and are no longer trying to move away. Haušild believes that the main root of the problems at Chánov began with the difficulty of Roma people to adapt to their new surroundings when they moved from the old flats in Old Most to modern flats in the new neighbourhood. ${ }^{59}$ Another problem was that all the tenants were seen as being Roma, erasing any individual characteristics they may have had. Originally some non-Roma people inhabited the northern part of Chánov, but they moved out and were replaced by Roma and the socially disadvantaged.

Some Roma moved into various hostels, which on the one hand was the result of the municipality's policy enacted for its own economic interests. On the other hand, it was the result of the tenants own indebtedness and inability to pay their bills. These areas are more often in neighbourhoods inhabited solely by the Roma population. Their displacement could have been avoided had the municipality taken other actions to prevent this. In addition, according to Víšek, the government does not see the Roma people as citizens who should be engaged politically or as potential voters, as their voices do not influence electoral results significantly. On the contrary, zero tolerance policies directed at the Roma tend to add political points. ${ }^{60}$

These hostels are often more expensive than the houses where people originally lived, there are no long-term tenancy agreements, and residents are forced to fulfil certain duties connected with the use of the flat or house. Failure to do so can result in eviction. They are often the worst possible accommodations in town, and as Radostný and Rưžička show, they can become factories for debt dodgers, especially when those paying their debts realize that doing so is not necessary; many families still maintain basic services without paying. ${ }^{61}$

\section{CONCLUSIONS}

We can conclude that in Czech socially excluded Roma areas, the processes of ghettoization and social exclusion are taking place together and strengthening each other. Studying the concept of ghettoization is useful because it draws attention to the results of social exclusion and the consequences that it can have not only for the excluded population, but also for the majority. At the same time drawing attention to these processes allows policy makers to understand the issue and create legislation that will aid in reversing the development of such areas.

The case of Poschla has brought to light the story of the most disadvantaged minority population in the Czech Republic, and it has argued that ghettoization came into existence here long before the container houses existed. The municipality's neglect of the balcony-access housing before 2006 created a homogeneous community of Roma, which was then forced to move to Poschla due to their

\footnotetext{
${ }^{59}$ Haušild, 'Kořeny chánovských problémů', p. 91.

${ }^{60}$ Petr Víšek, 'Vytěsňování romských komunit', in Prevence prostorové segregace, ed. by Luděk Sýkora and Jana Temelová (Praha: Univerzita Karlova, Ministerstvo pro místní rozvoj, 2005), pp. 91-95.

${ }^{61}$ Radostný and Růžička, 'Masokombinát Kladno', p. 251.
} 
outstanding debts. Poschla serves as a place of control and confinement of the Roma population, keeping them excluded from everyday interaction with the non-Roma people. These processes are currently taking place, and many people in Poschla have lost any hope of finding different accommodation. In addition, stigmatization by the majority has closed the community both from the outside as well as from the inside. It is of utmost importance to use sociological terms properly, and studies similar to this one will help answer the question of whether ghettos exist in Czech cities.

This work is licensed under the Creative Commons Attribution-Non-Commercial CC-BY-NC 2.0 UK: England $\mathcal{E}$ Wales License. Under the terms of this license, you are allowed to build upon this work non-commercially, but must give the original author credit and license your new creation under the identical terms. To view a full copy of this license, visit: http://creativecommons.org/licenses/ or send a letter to Creative Commons, 444 Castro Street, Suite 900, Mountain View. 